\title{
Impact of Different Mulching Materials on the Growth and Yield of tomato (Solanum lycopersicum) in Dehradun region of Uttarakhand
}

\author{
Rohit Pinder, Renu Rana, Devashree Maan, Kuldip Kumar
}

Hemwati Nandan Bahuguna Garhwal University, Srinagar, Garhwal, Uttarakhand, India

\begin{abstract}
Field trials were carried out in 2013-2014 cropping seasons to assess the impact of different mulching materials on the growth and yield of tomato (Solanum lycopersicum) in Dehradun (Uttarakhand) region of India. The crop growth and fruit yield were studied for two cultivars namely Cherry Tomato and Marglobe under two inorganic mulches (black polythene, white polythene) and four organic mulches (FYM, rice straw, dry leaves, sugarcane trash) and compared with unweeded control. Four competitive plants were randomly selected from each treatment to record data on various parameters. The experiment comprising these treatments was laid out as factorial randomized block design with three replications. It was observed that among all the treatments black polythene mulch showed significantly higher plant height $(89.92 \mathrm{~cm}, 59.17 \mathrm{~cm})$ and $(97.17 \mathrm{~cm}, 63.42 \mathrm{~cm})$ after 30 and 45 days respectively, number of trusses per plant (109 and 6.33), number of fruits per truss (14.50 and 6.42) and weight of immature and mature fruits (4.59 gm and $6.73 \mathrm{gm})$ and $(42.08 \mathrm{gm}$ and $54.25 \mathrm{gm}$ ) in Cherry Tomato and Marglobe varieties. Among all the treatments, black polythene mulch was found to be the best for tomato cultivation in Dehradun (Uttarakhand) region of India.
\end{abstract}

Keywords- Tomato, Truss, Growth, Yield, Organic mulch, Plastic mulch.

\section{INTRODUCTION}

Tomato (SolanumlycopersicumL.) is one of the most important vegetable crop belongs to the family Solanaceae. It is rich source of vitamin A, B and iron.It is mostly used for fresh vegetable, salad and processing products like puree, ketchup, sauce etc. It is an important off season crop of Uttarakhand area. Due to terrace cultivation and rainfed irrigation system water is a major constraint and there is a need to conserve moisture. Moreover, labour is a big constraint in this area. Therefore, use of mulches is imperative to conserve soil moisture, reduce weed growth, improves the fruit yield, productivity as well as reducing production cost. Since, the land holdings are very small in this region; therefore, there is a need of conservation farming and sustainable agriculture to improve the environment. There are several organic and inorganic mulches, but due to the property of reflectance of plastic mulches, they are used more or much beneficial to minimize the incidence of viral diseases and deter the approach to some species of insectpests. The potential of mulches to improve soil structure, increase organic matter, and establish patterns of nutrient cycling more similar to natural ecosystems has been recognized. Polyethylene mulches have induced large increases in growth and yields for tomato. (Samih M. Abubaker, 2013).However, it is also needed to find out which mulch is good.Use of mulches for crop offers great scope to plant growth by improving water infiltration, retention, and reducing runoff. It reduces and controls soil erosion by providing a cover on the soil surface (Erenstein, 2002).

Keeping in view, the present investigations were carried out with the objective of studying the "Impact of different mulching materials on the growth and yield of tomato (Solanumlycopersicum) in Dehradun region of Uttarakhand".

\section{MATERIALS AND METHODS}

A field experiment was carried out at Research Area, Department of Horticulture, DCAST, Selaqui, Dehradun (Uttarakhand) during 2013-2014 cropping season. This experiment was consisted of two varieties namely Cherry tomato and Marglobe with seven mulching treatment combinations viz. black polythene mulch (BPM), white polythene mulch (WPM), farmyard manure mulch (FYM), rice straw mulch (RSM), dry leaves mulch (DLM), sugarcane trash mulch (STM) and no mulch (control). The experimental design was factorial RBD and each treatment was replicated thrice. Plants height, were measured with the help of measuring tape after 30 and 45 days of transplanting from four plants in each replication 
of different treatments. Numbers of trusses per plant, number of fruits per truss were counted manually and carefully after the onset of fruiting stage in both the varieties. The tomatoes were harvested at two different stages of development i.e. green (immature) and red (mature) and weighed using an electronic weighing machine. Harvested tomatoes usedfor weighing wereuniform, healthy and free from insect-pests, diseases and bruises. The data was analyzed at 5\% level of significance statistically by using OPSTAT statistical software of Chaudhary Charan Singh Haryana Agricultural University, Hisar, Haryana.

\section{RESULTS AND DISCUSSION}

A significant effect onplant height at 30 days after transplanting was found for varieties, mulches and their interaction as shown in Table 1. The maximum value was found in Cherry Tomato $(77.33 \mathrm{~cm})$ which was significantly higher than MarglobeVariety $(53.52 \mathrm{~cm})$. Maximum value among mulches,plant height was found in black polythene mulch $(74.77 \mathrm{~cm})$ which was at par with farmyard manure mulch and higher than all other treatments, whereas minimum was observed in control $(51.78 \mathrm{~cm})$. The interaction data reveals thattallest plants $(89.92 \mathrm{~cm})$ were observed with black polythene mulch in Cherry Tomato variety which was at par with farmyard manure mulch in the same variety and found higher with all the treatment combinations. However, minimum plant height $(40.89 \mathrm{~cm})$ was observed with control in Marglobe Variety.

Comparison of data in Table 2 reveals that significant variations were found onplant height at 45 days after transplanting for varieties, mulches and their interaction. Maximum value was observed in Cherry tomato (84.57 $\mathrm{cm}$ ) which was significantly higher than Marglobe variety $(56.78 \mathrm{~cm})$.Tallest plants were found in black polythene mulch $(80.29 \mathrm{~cm})$ which was at par with farmyard manure mulch and higher than all other treatments, whereas shortest was observed in control $(56.25 \mathrm{~cm})$. Interaction effect of varieties with mulches reveals that tallest plants were found with black polythene mulch $(97.17 \mathrm{~cm})$ in VarietyCherry tomato which was at par with farmyard manure mulch in the same variety and found higher with all the treatment combinations. However, minimum plant height $(42.92 \mathrm{~cm})$ was observed with control in Marglobe variety. Maximum plant height was recorded with polythene mulch due to their warming effect of polythene mulch as compare to other organic mulch or control (Ham et al., 1993). Higher soil temperatures increase nutrient availability, enhance nutrient uptake by roots, increase the number and activity of soil microorganisms, and speed up plant germination and growth (Larioset al., 1998). Similar results were obtained by Kayumet al. (2008), that mulching had significant effects on plant growth components.

Significant effects were found onnumber of trusses per plantfor varieties, mulches and their interaction (Table 3). Maximum value was observed in Cherry tomato (75.80) which was significantly higher than Marglobevariety (5.20). Maximum value w.r.t mulches were found in black polythene mulch (57.67) which was higher than all other treatments, whereas minimum was observed in control (32.88). Interaction effect of varieties with mulches reveals that maximum trusses were found with black polythene mulch (109.00) in Cherry tomato which was found higher than all the treatment combinations. However, minimum value (4.57) was observed with control in Marglobe variety.This might be due to inherent genetic characteristics.However, maximum number of trusses/plant was recorded with polythene mulch due to increase the moisture content of the soil through decreased evaporation and surface runoff with consequent increase in yield and crop yield components (Gudugiet al.,2012).

Table 4 shows significant results w.r.t number of fruits per truss among cultivars, mulches and their interaction. Maximum fruits were found in Cherry tomato (12.33) which was higher than Marglobe variety (4.64). Comparison of different mulches showed that maximum value (10.46) was found with black polythene mulchwhich was significantly higher than other mulchingtreatments, whereas minimum value was found in control(6.58). Maximum value (14.50) was observed with black polythene mulch in Cherry tomato which was at par with white polythene mulch in the same variety and found higher with all mulches in both the varieties. However, minimum number of fruits per truss was observed with control (3.25) in Marglobe variety. Similar results were obtained by Hedauet al. (2010) that among mulches, black polyethylene treatment produced significantly higher fruit yield and number of fruits per plant than organic mulches and no mulch this might be the result of weed free field, less nutrient loss through leaching favourable soil temperature and moisture, these findings are in agreement with and Kashyapet al. (2009). Nikolicet al. (2012) have also reported similar results that highest number of fruits per plant was recorded in the plants grown on the plastic mulch than those on organic mulches and control (no mulch). Similar findings were also obtained mulched and non-mulched plots by Hudu $e t$ al.(2002), RajbirSingh (2005), Arunaet al. (2007), Nagalakshmiet al. (2002).

It is clear from the Table 5 that significant variations were observed on weight of immature/ green tomatoes w.r.t cultivars, mulches and their interactions.Maximum value of fruits weight was observed by Marglobe variety 
$(36.86 \mathrm{~g})$ which was higher than Cherry tomato $(3.64 \mathrm{~g})$. Maximum value w.r.t mulches was found in black polythene mulch $(23.34 \mathrm{~g})$ which was at par with all other treatments except sugarcane trash mulch and control, whereas minimum value was observed in control $(14.74 \mathrm{~g})$. The interaction data reveals thatmaximum weight of immature fruits $(42.08 \mathrm{~g})$ were observed with black polythene mulch in Marglobe variety which was at par with white polythene mulch and farmyard manure mulch in the same variety and found higher with all the treatment combinations. However, minimum value of fruits weight $(3.03 \mathrm{~g})$ was observed with control in Cherry tomato variety.

Significant effects were found onweight of mature/ red tomatoes w.r.t cultivars, mulches and their interactions (Table 6). Maximum value was observed in Marglobe variety $(49.25 \mathrm{~g})$ was significantly higher than Cherry tomato variety $(4.35 \mathrm{~g})$.Maximum value w.r.t mulches were found in black polythene mulch $(30.48 \mathrm{~g})$ which was at par with white polythene mulch and found higher than all other treatments, whereas minimum was observed in control $(23.64 \mathrm{~g})$. Interaction effect of varieties with mulches reveals that maximum weight of fruits was found with black polythene mulch $(54.25 \mathrm{~g})$ in Marglobe varietywhich was at par with white polythene mulch and dry leaves mulch in the same variety. However, minimum value $(3.29 \mathrm{~g})$ was observed with control in Cherry tomato. Agrawal et al.(2010) observed that weight of fruits under mulch conditions was found to be highest and same characters were lowest in control or no mulch treatments. This increase in tomato yield may be due to the better development of roots and vegetative growth, better nutrients uptake in mulched plots, and less normal leaching of nitrogen, Similarly Nikolicet al. (2012) reported the highest weight of fruits was achieved by mulching the soil with the plastic mulch and the lowest with cultivation on the soil (control).Similarly, Baye(2011) reported that tomato grown under plastic mulches resulted in significant increase in yield, earliness and fruit quality.

\section{CONCLUSION}

Significant effects of soil mulches on the investigated tomato cultivars parameter including plant height,number of trusses per plant, number of fruits per truss, weight of immature/ green tomatoes and weight of mature/ red tomatoes under Dehradun (Uttarakhand) region of India. Due to hilly area some parameters like soil erosion and cultural practices may be very difficult to control soil and plant ecosystem and weeds control, so there is need to conserve the soil and plant environment by using mulches.From the results of this study, it could be concluded that black polythene mulch showed the general desirable impacts under this region on tomato growth and yielding performance.

\section{REFERENCES}

[1] Agrawal, N, Panigrahi, H.K., Sharma, D., and Agrawal, R. 2010. Effect of different colour mulches on the growth and yield of tomato under Chhattisgarh region.Indian Journal of Horticulture67: 295-300.

[2] Aruna, P, Sudagar, I.P., Manivannan, M.I., Rajangam, J., and Natarajan, S. 2007. Effect of fertigation and mulching for yield and quality in tomato cv. PKM-1.Asian Journal of Horticulture 2(2): 50-4.

[3] Baye, B. 2011.Effect of mulching and amount of water on the yield of tomato grown under drip irrigation.Journal of Horticulture \& Forestry3(7): 200-206.

[4] Erenstein, O. 2002.Crop residue mulching in tropical and semi-tropical countries: An evaluation of residue availability and other technological implications. Soil and Tillage Research67:115-133.

[5] Farias-Larios, J, Orozco-Santos, M., and Perez, J. 1998.Effect of plastic mulch, floating row covers and microtunnels on insect population and yield of muskmelon.Proc NatlAgriPlastCongr 27:76-83.

[6] Gudugi, I.A.S., Odofin, A.J., Adeboye, M.K.A., and Oladiran, J.A.2012.Agronomic characteristics of tomato as influenced by irrigation and mulching.Advances in Applied Science Research3(5): 2539-2543.

[7] Ham, J.M., Kluitenberg, G.J., and Lamont, W.J.1993.Optical properties of plastic mulches affect the field temperature regime. Journal of the American Society for Horticultural Science118:188193.

[8] Hedau, N.K, Ranjan, J.K, Das, B, Pragya, Verma, R.K., and Sofi, A.A. 2010. Effect of bio-fertilization and mulch treatments on yield attributes and fruit quality of tomato under hill conditions of Uttarakhand.Indian Journal of Horticulture67(Special Issue): 259-2.

[9] Hudu, A.I., Futuless, K.N., and Gworgwor, N.A. 2002. Effects of mulching intensity on the growth and yield of irrigated tomato (LycopersiconesculentumMill.) and weed infestation in semi-arid zone of Nigeria.Journal of Sustainable Agriculture 21:37-45.

[10] Kashyap, S., Phookan, D.B., Baruah, P., and Bhuyan, P.2009.Effect of drip irrigation and polythene mulch on yield, quality, water-use efficiency and economics of broccoli production.Indian J. Hort 66: 390-92. 
[11] Kayum, M.A., Asaduzzaman, M. and Haque, M.Z. 2008.Effects of indigenous mulches on growth and yield of tomato. J. Agric. Rural Dev6(1\&2): 1-6.

[12] Nagalakshmi, S., Palanisamy, D., Eswaran, S., and Sreenarayanan, V.V.2002. Influence of plastic mulching on chilli yield and economics. South Indian Horticulture 50: 262-265.

[13]Nikolic, B., Radulovići, M., Spalevic, V., and Nenezic. E. 2012. Mulching methods and their effects on the yield of tomato (Lycopersiconesculentum, Mill.) in the zeta
plain.Agriculture \& Forestry, Vol52 (06) (1-4): 1733, Podgorica.

[14] RajbirSingh.2005. Influence of mulching on growth and yield of tomato (SolanumlycopersicumL.) in North Indian plains. Vegetable Science32(1): 55-58.

[15] Samih, M. Abubaker. 2013. Effect of different types of mulch on performance of tomato (Lycopersiconesculentum Mill.) under plastic house conditions. Journal of Food, Agriculture \& Environment11(2): 684-686.

Table. 1: Effect of mulches on Plant height after 30 days of transplanting (cm)of cultivars Cherry tomato and Marglobe

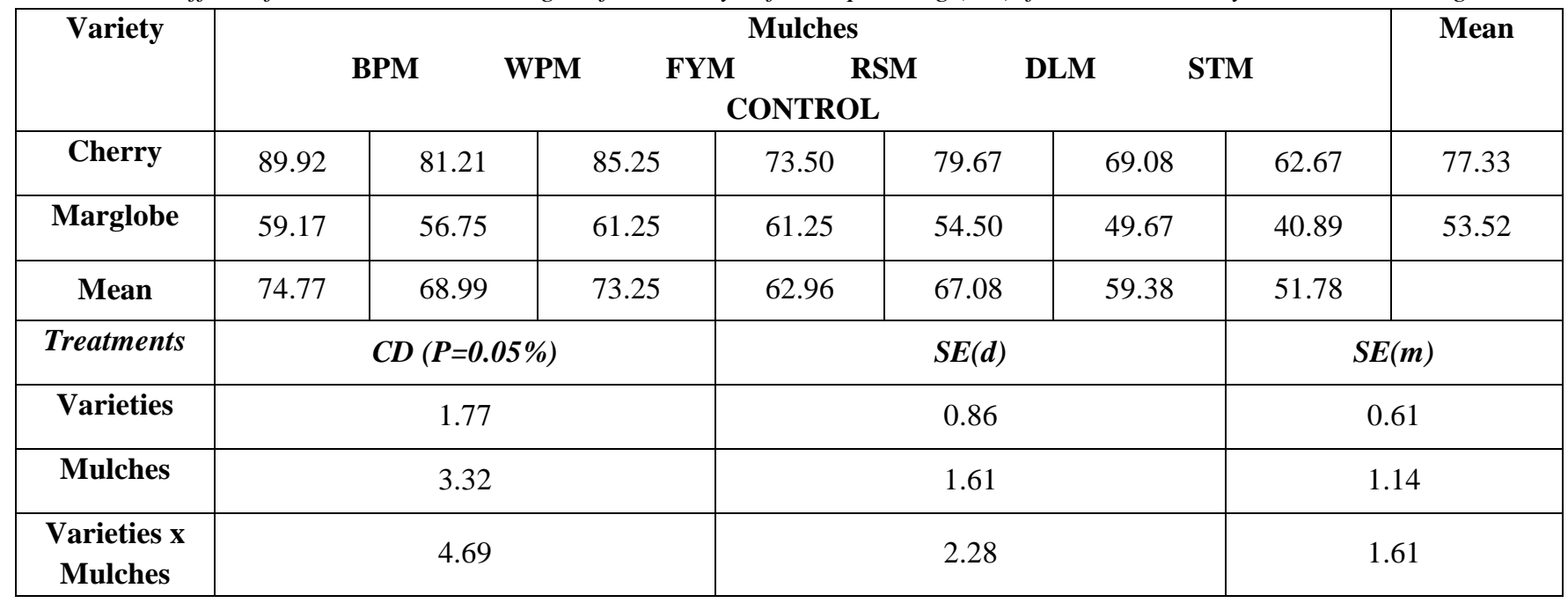

Where, $\mathbf{B P M}=$ black polythene mulch, $\mathbf{W P M}=$ white polythene mulch, $\mathbf{F Y M}=$ farmyard manure mulch, $\mathbf{R S M}=$ rice straw mulch, DLM = dry leaves mulch, STM = sugarcane trash mulchand CONTROL = no mulch.

Table. 2:Effect of mulches on Plant height after 45 daysaftertransplanting (cm) of cultivars Cherry tomato and Marglobe

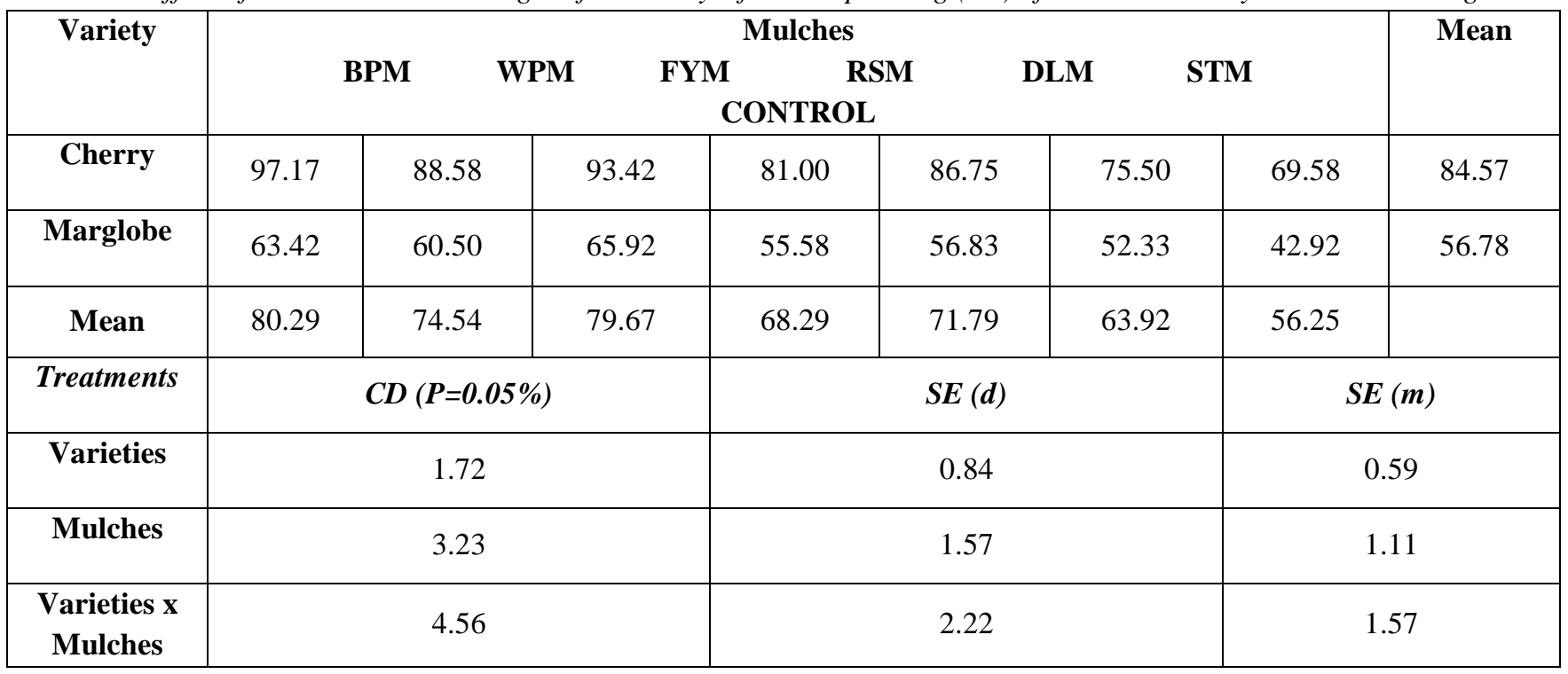

Where, BPM = black polythene mulch, WPM = white polythene mulch, FYM = farmyard manure mulch, RSM = rice straw mulch, DLM = dry leaves mulch, STM = sugarcane trash mulchand $\mathbf{C O N T R O L}=$ no mulch. 
Table.3: Effect of mulches on Number of trusses/plantof cultivars Cherry tomato and Marglobe

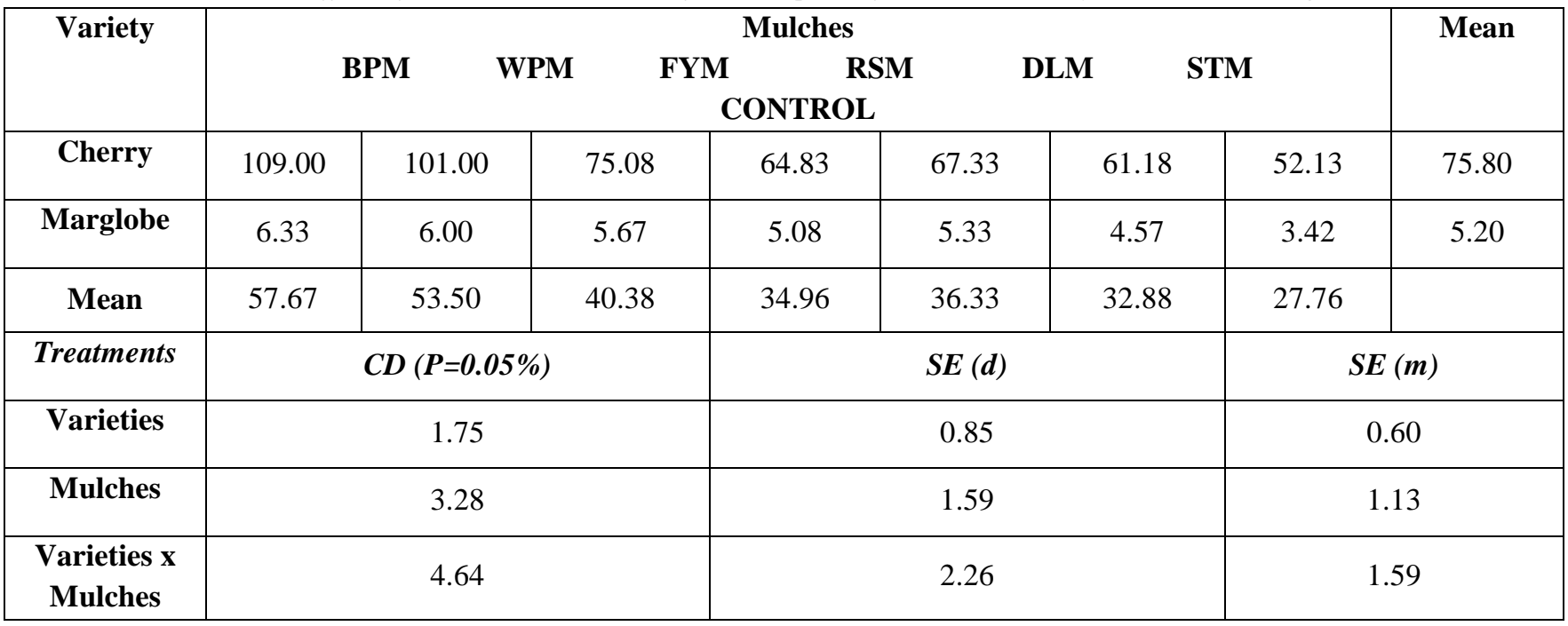

Where, $\mathbf{B P M}=$ black polythene mulch, $\mathbf{W P M}=$ white polythene mulch, $\mathbf{F Y M}=$ farmyard manure mulch, $\mathbf{R S M}=$ rice straw mulch, DLM = dry leaves mulch, STM = sugarcane trash mulchand CONTROL = no mulch.

Table.4: Effect of mulches on Number of fruits/truss of cultivars Cherry tomato and Marglobe

\begin{tabular}{|c|c|c|c|c|c|c|c|c|}
\hline \multirow[t]{2}{*}{ Variety } & \multicolumn{7}{|c|}{ Mulches } & \multirow[t]{2}{*}{ Mean } \\
\hline & BPM & WPM & FYM & RSM & DLM & STM & CONTROL & \\
\hline Cherry & 14.50 & 14.08 & 13.67 & 11.75 & 12.17 & 10.67 & 9.92 & 12.33 \\
\hline Marglobe & 6.42 & 5.17 & 4.75 & 4.25 & 4.67 & 4.00 & 3.25 & 4.64 \\
\hline Mean & 10.46 & 9.63 & 9.21 & 8.00 & 8.42 & 7.33 & 6.58 & \\
\hline Treatments & \multicolumn{3}{|c|}{$C D(P=0.05 \%)$} & \multicolumn{3}{|c|}{$S E(d)$} & \multicolumn{2}{|c|}{$S E(m)$} \\
\hline Varieties & \multicolumn{3}{|c|}{0.27} & \multicolumn{3}{|c|}{0.13} & \multicolumn{2}{|c|}{0.93} \\
\hline Mulches & \multicolumn{3}{|c|}{0.51} & \multicolumn{3}{|c|}{0.25} & \multicolumn{2}{|c|}{0.17} \\
\hline $\begin{array}{c}\text { Varieties x } \\
\text { Mulches }\end{array}$ & \multicolumn{3}{|c|}{0.71} & \multicolumn{3}{|c|}{0.35} & \multicolumn{2}{|c|}{0.24} \\
\hline
\end{tabular}

Where, BPM = black polythene mulch, $\mathbf{W P M}=$ white polythene mulch, $\mathbf{F Y M}=$ farmyard manure mulch, $\mathbf{R S M}=$ rice straw mulch, DLM = dry leaves mulch, STM = sugarcane trash mulchand CONTROL = no mulch.

Table.5: Effect of mulches on Weight of immature (green) tomatoes ( $g$ ) of cultivars Cherry tomato and Marglobe

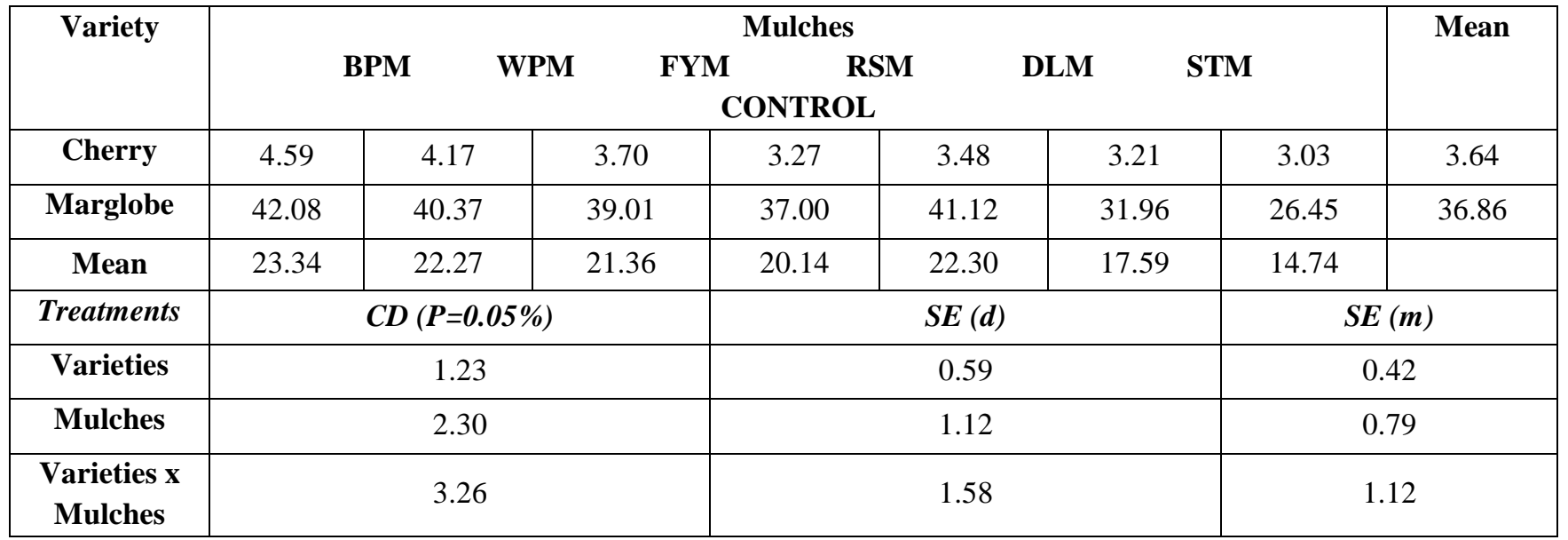


Where, BPM = black polythene mulch, $\mathbf{W P M}=$ white polythene mulch, $\mathbf{F Y M}=$ farmyard manure mulch, $\mathbf{R S M}=$ rice straw mulch, DLM = dry leaves mulch, STM = sugarcane trash mulchand CONTROL = no mulch.

Table.6: Effect of mulches on Weight of mature (red) tomatoes ( $g$ ) of cultivars Cherry tomato and Marglobe

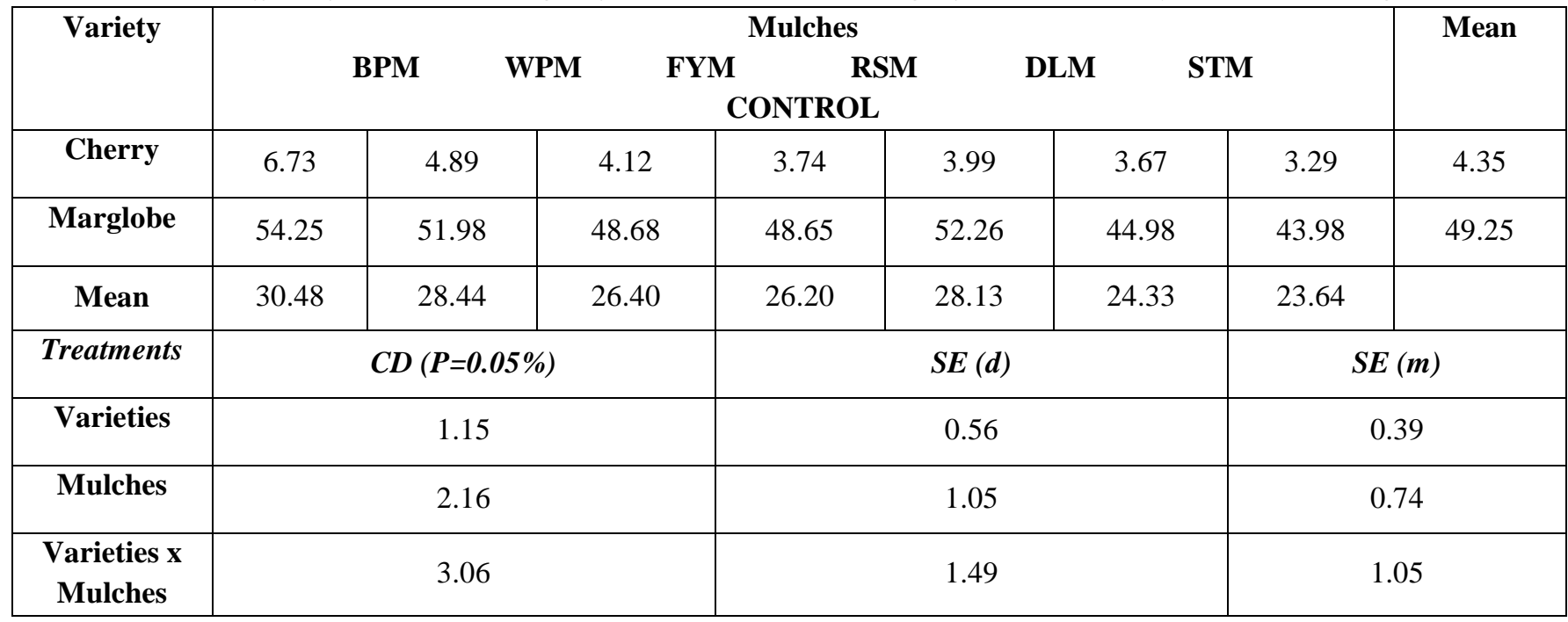

Where, BPM = black polythene mulch, WPM = white polythene mulch, FYM = farmyard manure mulch, $\mathbf{R S M}=$ rice straw mulch, DLM = dry leaves mulch, STM = sugarcane trash mulchand CONTROL = no mulch. 